\title{
The Contents of Microelements and Exogenous Amino Acids in Spring Wheat (Triticum aestivum L.) Grain after Municipal Sewage Sludge Fertilization
}

\author{
Krzysztof Gondek ${ }^{1}$, Michał Kopeć ${ }^{1} \&$ Tomasz Głąb ${ }^{2}$ \\ ${ }^{1}$ Department of Agricultural and Environmental Chemistry, University of Agriculture in Krakow, Poland \\ ${ }^{2}$ Institute of Machinery Exploitation, Ergonomics and Production Processes, University of Agriculture in Krakow, \\ Poland \\ Correspondence: Tomasz Głąb, Institute of Machinery Exploitation, Ergonomics and Production Processes, \\ University of Agriculture in Krakow, Poland. E-mail: rtglab@cyf-kr.edu.pl
}

Received: July 29, 2011 Accepted: September 11, 2012 Online Published: November 26, 2012

doi:10.5539/jas.v4n12p294 URL: http://dx.doi.org/10.5539/jas.v4n12p294

\begin{abstract}
The research was conducted to assess the effect of municipal sewage fertilization on the contents of microelements and exogenous amino acids in grain of spring wheat (Triticum aestivum L.). The investigations were conducted as a field experiment in the years 2005-2007 on the silt loam soil classified as Stagnic Gleysol. The experimental design comprised 5 treatments of fertilization in four replications: unfertilized control (0), mineral materials (M), pig manure (PM), municipal sewage sludge from mechanical-biological treatment plant (SS1) and municipal sewage sludge from biological treatment plant (SS2). On the basis of obtained results it was stated that difficult access of plants to nitrogen supplied with sewage sludge may considerably determine the crop yield and its quality, particularly in the first year after the fertilizers application. Applied doses of sewage sludge did not affect significantly the contents of analyzed microelements or exogenous amino acids. Irrespective of applied fertilization, the microelements which reduced fodder value of spring wheat were copper and manganese, whereas protein concentrations were determined by lysine content.
\end{abstract}

Keywords: spring wheat, sewage sludge, microelements, exogenous amino acids

\section{Introduction}

Balanced fertilization is one of the crucial elements of sustainable agriculture. Rational management of nutrients allows not only maintaining but also gradually increasing yield forming potential of agricultural soils. Recycling the elements, either as mineral or natural fertilizers or organic waste materials (sewage sludge) to the soil, seems justified not only from the economic point of view but is also necessary to restore ecological equilibrium in agrocenoses. Despite numerous investigations, not all doubts concerning environmental and agricultural utilization of municipal sewage sludge have been clarified (Chaudri et al., 2001; Sastre et al., 2001; Korbulewsky et al., 2002; Gondek, 2006a). The use of these materials in agriculture remains the subject of discussions and raises doubts concerning their microbiological and chemical properties but also technical means of their application. However, the tendency to manage currently existing and produced sewage sludge in agriculture has been considered as the closest to the natural ecosystem in which producers' waste substances become substrate for reducers and consumers (Ahmad et al., 2006; Mohammad \& Athamneh, 2004). It is justified because of recycling organic substance, nutrients and microelements to the circulation. On the other hand, sewage sludge is a material enriched with substances or elements, such as trace elements which may pose a hazard for the cleanliness of the soil environment and plant quality (Lavado et al., 2005).

Trace element content, including microelements, in plants does not result only from their chemical properties or soil properties but is determined by the element quantity supplied to the soil with fertilizers and by the plant abilities for its absorption. Microelements are crucial for plants due to their functions in the metabolism as components and activators of enzymes. These elements also affect the course of many processes which occur in plants, among others the photosynthesis, nitrogen transformations, but also synthesis of amino acids (Prasad, 1995; Rüegsegger et al., 1991). 
The hypothesis of the presented research assumed that while using municipal sewage sludge for fertilization one may expect their advantageous effect not only on spring wheat grain yield but also on its biological value. The aim of the investigations was an assessment of the effect of municipal sewage sludge fertilization on the contents of microelements and exogenous amino-acids in spring wheat grain. The research was conducted for three years as a field experiment.

\section{Materials and Methods}

\subsection{Site, Location and Climate}

The investigations were conducted as a field experiment located $10 \mathrm{~km}$ west of Krakow, Poland $\left(49^{\circ} 59^{\prime} \mathrm{N}\right.$; $\left.19^{\circ} 41^{\prime} \mathrm{E}\right)$. The climate in the experimental site is temperate with an average annual precipitation of $686 \mathrm{~mm}$, and mean daily temperature of $11.0^{\circ} \mathrm{C}$. The field experiment was located on Stagnic Gleysol soil (IUSS Working Group WRB, 2007). Table 1 reports the basic soil characteristics at the experimental site.

Table 1. Soil characteristics of Stagnic Gleysol from trial location in Czernichow (0-20 cm layer)

\begin{tabular}{lll}
\hline Soil property & Unit & Value \\
\hline $\mathrm{pH}(\mathrm{KCl})$ & & 5.6 \\
Total organic C & $\mathrm{g} \mathrm{kg}^{-1}$ & 15.3 \\
$\mathrm{~N}$ & $\mathrm{~g} \mathrm{~kg}^{-1}$ & 1.59 \\
$\mathrm{P}$ & $\mathrm{mg} \mathrm{kg}^{-1}$ & 71.8 \\
$\mathrm{~K}$ & $\mathrm{mg} \mathrm{kg}^{-1}$ & 297.5 \\
$\mathrm{Cu}_{\text {tot }}$ & $\mathrm{mg} \mathrm{kg}^{-1}$ & 15.8 \\
$\mathrm{Zn}_{\text {tot }}$ & $\mathrm{mg} \mathrm{kg}^{-1}$ & 132.8 \\
$\mathrm{Mn}_{\text {tot }}$ & $\mathrm{mg} \mathrm{kg}^{-1}$ & 2230 \\
$\mathrm{Fe}_{\text {tot }}$ & $\mathrm{mg} \mathrm{kg}^{-1}$ & 25650 \\
Bulk density & $\mathrm{g} \mathrm{cm}^{-3}$ & 1.52 \\
Solid particle density & $\mathrm{g} \mathrm{cm}^{-3}$ & 2.58 \\
Total porosity & $\mathrm{cm}^{3} \mathrm{~cm}^{-3}$ & 0.41 \\
Sand & $\mathrm{g} \mathrm{kg}^{-1}$ & 280 \\
Silt & $\mathrm{g} \mathrm{kg}^{-1}$ & 580 \\
Clay & $\mathrm{g} \mathrm{kg}^{-1}$ & 140 \\
Texture & & Silty loam \\
\hline
\end{tabular}

\subsection{Experimental Design and Treatments}

The experiment was set up in a randomized block design with four replications and a plot area of $30 \mathrm{~m}^{2}$. Five treatments were evaluated:

unfertilized soil (0), mineral fertilization (M), $110 \mathrm{~kg} \mathrm{~N} \mathrm{ha}^{-1}, 58.6 \mathrm{~kg} \mathrm{Pha}^{-1}$ and $120 \mathrm{~kg} \mathrm{~K} \mathrm{ha}^{-1}$ ), pig manure (PM) fertilization with the rate of $14.30 \mathrm{tha}^{-1}$ fresh matter, municipal sewage sludge from mechanical-biological treatment plant (SS1) (a rate of $14.15 \mathrm{t} \mathrm{ha}^{-1}$ fresh matter) municipal sewage sludge from biological treatment plant (SS2) fertilization with the rate of $10.26 \mathrm{tha}^{-1}$ fresh matter.

Selected properties of the manure and municipal sewage sludge are presented in Table 2 . The field was limed before the experiment outset (in autumn 2004) at a rate of $962.0 \mathrm{~kg} \mathrm{CaO} \mathrm{tha}^{-1}$ (rate determined according to $1 / 2$ hydrolytic acidity). In spring 2005 manure and sewage sludge were applied evenly on the plots, which were then ploughed. Two weeks later a supplementary mineral fertilization was applied, the fertilizers were mixed with the soil using cultivator/harrow aggregate. Nitrogen fertilization rate was of $110.0 \mathrm{~kg} \mathrm{~N} \mathrm{t} \mathrm{ha}{ }^{-1}$. Phosphorus and potassium were applied to the equal level on all treatments (phosphorus of $58.6 \mathrm{~kg} \mathrm{P} \mathrm{ha}^{-1}$ in a single 
superphosphate and potassium of $120.0 \mathrm{~kg} \mathrm{~K} \mathrm{ha}^{-1}$ in $60 \%$ potassium salt), except the control. In the second and third year of the research the rates of the NPK elements were applied identical as in the first year, but only as mineral fertilizers, in order to supplement nitrogen, phosphorus and potassium absorbed by wheat yield.

Table 2. Physical and chemical properties of the organic fertilizers.

\begin{tabular}{|c|c|c|c|c|}
\hline & & Pig manure (PM) & $\begin{array}{c}\text { Sewage sludge, } \\
\text { Krzeszowice (SS1) }\end{array}$ & $\begin{array}{l}\text { Sewage sludge, } \\
\text { Czernichow (SS2) }\end{array}$ \\
\hline $\mathrm{N}_{\text {tot }}$ & $\mathrm{g} \mathrm{kg}^{-1}$ d.m. & 34.0 & 26.2 & 41.6 \\
\hline $\mathrm{P}_{\text {tot }}$ & $\mathrm{g} \mathrm{kg}^{-1} \mathrm{~d} . \mathrm{m}$. & 12.8 & 8.2 & 22.3 \\
\hline $\mathrm{K}_{\text {tot }}$ & $\mathrm{g} \mathrm{kg}^{-1}$ d.m. & 21.8 & 1.9 & 1.2 \\
\hline $\mathrm{Cu}_{\text {tot }}$ & $\mathrm{mg} \mathrm{kg}^{-1}$ d.m. & 156 & 103 & 80 \\
\hline $\mathrm{Zn}_{\text {tot }}$ & $\mathrm{mg} \mathrm{kg}^{-1}$ d.m. & 284 & 1146 & 950 \\
\hline $\mathrm{Mn}_{\text {tot }}$ & $\mathrm{mg} \mathrm{kg}^{-1}$ d.m. & 355 & 194 & 112 \\
\hline $\mathrm{Fe}_{\mathrm{tot}}$ & $\mathrm{mg} \mathrm{kg}^{-1}$ d.m. & 2158 & 47779 & 5391 \\
\hline $\mathrm{EC}^{\mathrm{a}}$ & $\mathrm{mS} \mathrm{cm}{ }^{-1}$ & 2.89 & 1.69 & 0.47 \\
\hline $\mathrm{pH}\left(\mathrm{H}_{2} \mathrm{O}\right)$ & & 8.23 & 6.23 & 6.57 \\
\hline Organic matter & $\mathrm{g} \mathrm{kg}^{-1}$ d.m. & 831 & 414 & 726 \\
\hline Water content & $\mathrm{g} \mathrm{kg}^{-1}$ f.m..$^{\mathrm{c}}$ & 774 & 703 & 742 \\
\hline Ash & $\mathrm{g} \mathrm{kg}^{-1}$ d.m. & 169 & 586 & 244 \\
\hline
\end{tabular}

${ }^{\mathrm{a}} \mathrm{EC}=$ electrical conductivity;

${ }^{\mathrm{b}}$ data are based on $105^{\circ} \mathrm{C}$ dry matter weight;

${ }^{\mathrm{c}}$ f.m. $=$ fresh matter.

A test plant in the presented investigations was spring wheat, Jagna cv., sown with the plant density of 485 plants $1 \mathrm{~m}^{-2}$. During vegetation period chemical protection was applied with herbicides Puma Universal (Bayer CropScience) at a rate of $11 \mathrm{ha}^{-1}$ and Aminopielik Gold (Makhteshim Agan Agro Poland S.A.) at a rate of $11 \mathrm{ha}^{-1}$ and Alert 375 fungicide (Du Pont) at a rate of $11 \mathrm{ha}^{-1}$.

\subsection{Harvesting}

Wheat was harvested at full grain maturity: on 13 August 2005 in the first year of the experiment, on 3 August 2006 in the second and on 31 July 2007 in the third. In order to determine wheat grain yield under field conditions the plants were harvested from the area of $4 \mathrm{~m}^{2}$, from each plot separately. The content of dry matter (DM) in the grain yield was assessed by drying $1000 \mathrm{~g}$ of grain at $70^{\circ} \mathrm{C}$ to constant weight.

\subsection{Sampling and Analysis of Pig Manure, Sewage Sludge, Soil and Plant Material}

Sewage sludge used in the experiment was obtained from two municipal treatment plants: mechanical-biological plant from Krzeszowice (SS1) and biological plant from Czernichów (SS2) situated in the Malopolska province (in the south of Poland). Manure used for the experiment was obtained from pig farm. Prior to the experiment outset it was stored on the manure slab for 6 months.

The content of dry matter was determined in fresh samples of sewage sludge and manure (at $105^{\circ} \mathrm{C}$ for $12 \mathrm{~h}$ ), pH by potentiometer, electrolytic conductivity by conductometer, total nitrogen after sample mineralization in concentrated sulphuric acid by Kjeldahl method. In the dried and ground material organic matter was determined using thermal method and mineral contents after sample mineralization in a muffle furnace (at $450^{\circ} \mathrm{C}$ for $5 \mathrm{~h}$ ) and dissolving the ash in diluted (1:2) v/v nitric acid. Phosphorus concentrations were assessed by colorimetry on Backman DU 640 spectrophotometer and potassium by means of flame photometry (FES) on Philips PU 9100X apparatus. The contents of copper, zinc, manganese and iron were assessed by means of ICP-AES method on JY 238 Ultrace apparatus. The analyses were conducted according to the methodology described in a paper by Baran and Turski (1996) and Krzywy (1999) and the results were presented in Table 2. 
The contents of microelements were determined in dried and ground wheat grain after sample dry mineralization in a muffle furnace $\left(450^{\circ} \mathrm{C}, 5 \mathrm{~h}\right)$ and dissolving the remains in a diluted (1:2) v/v nitric acid (Ostrowska et al., 1991). The contents of investigated elements were determined in the prepared solutions using ICP-AES method on JY 238 Ultrace apparatus. The contents of analyzed amino acids were assessed on AAA-400 (INGOS) analyzer following protein hydrolysis in $6 \mathrm{~mol} \mathrm{dm}^{-3} \mathrm{HCl}\left(110^{\circ} \mathrm{C}, 24 \mathrm{~h}\right)$. Methionine concentration was determined after oxidation with formic acid (AOAC, 1990).

The chemical score (CS) was calculated according to the method of Block and Mitchell (Beza, 1967) (Eq. 1) which relies on determining the ratio of the exogenous limiting amino acid in the analyzed protein (a) to the amino acid content in the standard protein (b):

$$
\mathrm{CS}=(\mathrm{a} / \mathrm{b}) \times 100
$$

Two standards were applied for the computations: the acids of the food protein composition appropriate for mature human (MH) and the amino acid composition of whole egg protein (WE) (Hidvégi \& Békés, 1984; FAO/WHO, 1991).

Chemical analysis of the plant material was conducted in 4 replications, whereas the initial materials (manure, sewage sludge and soil) in two replications and a plant reference material-NCS DC73348 (China National Analysis Center for Iron \& Steel) or soil reference-AgroMAT AG-2 (SCP Science) was added to each analyzed series. The result was considered reliable if the relative standard error did not exceed $5 \%$.

\subsection{Statistic}

The effect of fertilization treatment on wheat grain yield, contents of the analyzed microelements, protein concentration and exogenous amino acids was evaluated via analysis of variance. Significance of differences between arithmetic means were verified on the basis of homogenous groups determined using Duncan test with the level of significance of $p<0.05$. The value of correlation coefficient ( $r$ ) was calculated for the concentrations of microelements and analyzed exogenous amino acids in grain by means of non-parametric Spearman rank test. All statistical computations and graphical representations of the results were made using Statistica 8.0 (StatSoft Inc., Tulsa, OK, USA).

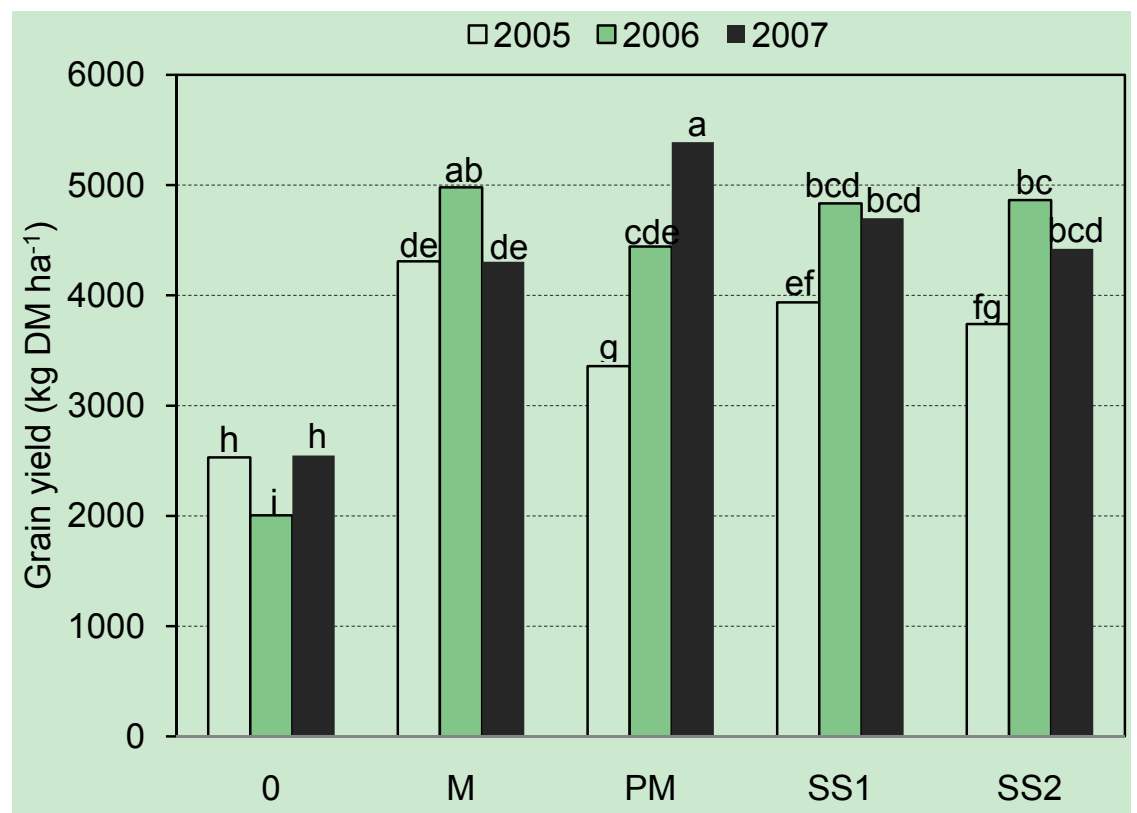

Figure 1. Dry matter (DM) yields of wheat grain for different years of the experiment. Different letters indicate significant differences $(\mathrm{p}<0.05$, Duncan's multiple range test)

\section{Results}

\subsection{Spring Wheat Grain Yield}

In the first year of the experiment the grain yields of spring wheat grain on the treatments which received pig manure (PM) and municipal sewage sludge (SS1 and SS2) were on average $3678 \mathrm{~kg} \mathrm{DM} \mathrm{ha}{ }^{-1}$ and they were 
approximately $700 \mathrm{~kg} \mathrm{DM} \mathrm{ha}^{-1}$ lower in comparison with the treatment where mineral fertilizers were applied (M) (Figure 1). The lowest yields were obtained at the control, unfertilised treatment (0), not only in 2005, but also in $2006\left(2006 \mathrm{~kg} \mathrm{DM} \mathrm{ha}^{-1}\right)$ and in $2007\left(2547 \mathrm{~kg} \mathrm{DM} \mathrm{ha}^{-1}\right)$. The effect of fertilisation applied and the differences in the amount of wheat grain were registered in the second year of the investigation. The difference between the lowest grain yield obtained after the application of pig manure $\left(4445 \mathrm{~kg} \mathrm{DM} \mathrm{ha}^{-1}\right)$ and the greatest quantity of wheat grain yield obtained as result of mineral fertilization $\left(4979 \mathrm{~kg} \mathrm{DM} \mathrm{ha}^{-1}\right)$ was slightly over $500 \mathrm{~kg} \mathrm{DM} \mathrm{ha}^{-1}$. In the third year of the experiment greater yields of spring wheat grain were gathered from the PM treatment (5390 kg $\left.\mathrm{DM} \mathrm{ha} \mathrm{a}^{-1}\right)$, particularly in comparison with the yields from the treatment where wheat was fertilized only with mineral fertilizers $\left(4305 \mathrm{~kg} \mathrm{DM} \mathrm{ha}^{-1}\right)$. No significant differences were registered between grain yield of spring wheat fertilized with sewage sludge from mechanical-biological treatment plant (SS1) and biological plant (SS2) during three years of experiment.

\subsection{Microelement Concentrations in Spring Wheat Grain}

Fertilization applied in the experiment diversified zinc content in spring wheat grain (Table 3). The smallest quantities of this element were assessed in wheat grain from the PM treatment (43.1 $\left.\mathrm{mg} \mathrm{kg}^{-1} \mathrm{DM}\right)$, the biggest amounts of zinc were in the wheat grain from the treatment where mineral fertilizers were used $\left(51.7 \mathrm{mg} \mathrm{kg}^{-1} \mathrm{DM}\right)$.

Table 3. Zinc, copper, manganese and iron content $\left(\mathrm{mg} \mathrm{kg}^{-1} \mathrm{DM}\right)$ and Fe:Mn ratio in grain of spring wheat. Means \pm standard error

\begin{tabular}{llllll}
\hline & \multicolumn{5}{c}{ Treatment } \\
\cline { 2 - 6 } & \multicolumn{1}{c}{0} & \multicolumn{1}{c}{ M } & \multicolumn{1}{c}{ PM } & \multicolumn{1}{c}{ SS1 } \\
\hline $\mathrm{Zn}$ & $49.7 \pm 4.02 \mathrm{a}$ & $51.7 \pm 1.68 \mathrm{a}$ & $43.1 \pm 3.99 \mathrm{~b}$ & $50.5 \pm 3.27 \mathrm{a}$ & $46.0 \pm 4.81 \mathrm{ab}$ \\
$\mathrm{Cu}$ & $3.61 \pm 0.51 \mathrm{a}$ & $3.37 \pm 0.72 \mathrm{a}$ & $3.35 \pm 0.96 \mathrm{a}$ & $3.55 \pm 0.84 \mathrm{a}$ & $3.26 \pm 0.71 \mathrm{a}$ \\
$\mathrm{Mn}$ & $27.9 \pm 4.60 \mathrm{a}$ & $28.3 \pm 2.49 \mathrm{a}$ & $24.9 \pm 4.73 \mathrm{a}$ & $28.9 \pm 2.94 \mathrm{a}$ & $24.7 \pm 4.37 \mathrm{a}$ \\
$\mathrm{Fe}$ & $153 \pm 26 \mathrm{~b}$ & $148 \pm 33 \mathrm{c}$ & $149 \pm 19 \mathrm{c}$ & $175 \pm 34 \mathrm{a}$ & $157 \pm 27 \mathrm{~b}$ \\
$\mathrm{Fe}: \mathrm{Mn}$ & $5.60 \pm 0.22 \mathrm{ab}$ & $5.21 \pm 0.28 \mathrm{~b}$ & $6.09 \pm 0.8 \mathrm{a}$ & $6.11 \pm 0.34 \mathrm{a}$ & $6.35 \pm 0.23 \mathrm{a}$ \\
\hline
\end{tabular}

Different letters in the same line indicate significant differences ( $\mathrm{p}<0.05$, Duncan's multiple range test).

No significant differences due to the applied fertilization were assessed in copper content in spring wheat grain (Table 3). The content of this element ranged from $3.26 \mathrm{mg} \mathrm{kg}^{-1} \mathrm{DM}$ (grain from the treatment on which sewage sludge from biological treatment plant (SS2) was used to $3.61 \mathrm{mg} \mathrm{kg}^{-1}$ dry matter (grain from the treatment where no fertilization was applied).

Considering the fertilized treatments, the highest amounts of manganese were determined in wheat grain fertilized with mineral fertilizers (M) and in grain from the treatment where municipal sewage sludge from the mechanical-biological treatment plan (SS1) was applied (Table 3).

Among the analysed elements, iron concentrations were the most diversified in wheat grain (Table 3). The smallest amounts of iron were found in wheat grain from the treatments on which mineral (M) and pig manure (PM) fertilization was applied, 148 and $149 \mathrm{mg} \mathrm{kg}^{-1} \mathrm{DM}$, respectively. Higher concentrations were noticed in wheat grain from the unfertilized treatment $\left(153 \mathrm{mg} \mathrm{kg}^{-1} \mathrm{DM}\right)$ and at the treatment where sewage sludge from biological treatment plant (SS2) was applied (157 $\left.\mathrm{mg} \mathrm{kg}^{-1} \mathrm{DM}\right)$. The highest contents of iron were determined in spring wheat grain fertilized with municipal sewage sludge from the mechanical-biological treatment plant $\left(175 \mathrm{mg} \mathrm{kg}^{-1} \mathrm{DM}\right)$.

The value of Fe:Mn ratio is greatly important for the assessment of plant supply with iron and manganese (Table 3). The Fe:Mn index varied from 5.21 at the M treatment to 6.35 at the SS2 object. Value of this index in spring wheat grain, irrespective of applied fertilization indicated manganese deficiency.

\subsection{Contents of Protein and Exogenous Amino Acids}

Total protein content was significantly higher in wheat grain from the fertilized treatments (M, PM, SS1 and SS2) than protein content in grain from the treatment where no fertilization was applied (0) (Table 4). Considering the treatments with fertilization, wheat grain fertilized with mineral materials $(\mathrm{M})$ contained the biggest quantities of total protein $\left(159.6 \mathrm{~g} \mathrm{~kg}^{-1} \mathrm{DM}\right)$. 
Table 4. Total protein content ( $\left.\mathrm{g} \mathrm{kg}^{-1} \mathrm{DM}\right)$ and composition of selected exogenous amino acids ( $\mathrm{g}^{100 \mathrm{~g}^{-1}}$ protein) in grain of spring wheat. Means \pm standard error

\begin{tabular}{|c|c|c|c|c|c|}
\hline & \multicolumn{5}{|c|}{ Treatment } \\
\hline & 0 & $\mathrm{M}$ & PM & SS1 & SS2 \\
\hline Total protein & $142.8 \pm 9.38 \mathrm{~b}$ & $159.6 \pm 6.1 \mathrm{a}$ & $154.6 \pm 11.7 \mathrm{a}$ & $158.0 \pm 14.2 \mathrm{a}$ & $157.8 \pm 13.5 \mathrm{a}$ \\
\hline Thr & $2.14 \pm 0.15 \mathrm{ab}$ & $2.19 \pm 0.14 \mathrm{a}$ & $2.17 \pm 0.13 \mathrm{ab}$ & $2.14 \pm 0.16 \mathrm{ab}$ & $2.01 \pm 0.15 \mathrm{~b}$ \\
\hline Val & $3.30 \pm 0.19 \mathrm{a}$ & $3.37 \pm 0.14 \mathrm{a}$ & $3.32 \pm 0.29 \mathrm{a}$ & $3.32 \pm 0.28 \mathrm{a}$ & $3.05 \pm 0.22 \mathrm{a}$ \\
\hline Ile & $2.37 \pm 0.14 \mathrm{ab}$ & $2.55 \pm 0.10 \mathrm{ab}$ & $2.66 \pm 0.17 \mathrm{a}$ & $2.56 \pm 0.23 \mathrm{ab}$ & $2.27 \pm 0.18 \mathrm{~b}$ \\
\hline Leu & $4.96 \pm 0.31 \mathrm{ab}$ & $5.18 \pm 0.23 \mathrm{a}$ & $4.27 \pm 0.47 \mathrm{~b}$ & $4.99 \pm 0.39 \mathrm{ab}$ & $4.75 \pm 0.32 \mathrm{ab}$ \\
\hline Phe & $3.17 \pm 0.20 \mathrm{ab}$ & $3.45 \pm 0.15 \mathrm{a}$ & $3.31 \pm 0.22 \mathrm{ab}$ & $3.32 \pm 0.28 \mathrm{ab}$ & $3.12 \pm 0.22 b$ \\
\hline Lys & $2.19 \pm 0.14 \mathrm{a}$ & $2.21 \pm 0.12 \mathrm{a}$ & $2.18 \pm 0.13 \mathrm{a}$ & $2.12 \pm 0.17 \mathrm{a}$ & $2.05 \pm 0.14 \mathrm{a}$ \\
\hline Met & $0.71 \pm 0.16 \mathrm{~b}$ & $0.72 \pm 0.13 \mathrm{~b}$ & $0.76 \pm 0.15 \mathrm{ab}$ & $0.79 \pm 0.17 \mathrm{a}$ & $0.72 \pm 0.13 \mathrm{~b}$ \\
\hline His & $2.14 \pm 0.05 \mathrm{a}$ & $2.12 \pm 0.05 \mathrm{a}$ & $2.15 \pm 0.09 \mathrm{a}$ & $2.19 \pm 0.13 \mathrm{a}$ & $2.09 \pm 0.07 \mathrm{a}$ \\
\hline Arg & $4.04 \pm 0.29 \mathrm{ab}$ & $4.45 \pm 0.23 \mathrm{a}$ & $4.23 \pm 0.29 \mathrm{ab}$ & $4.20 \pm 0.35 \mathrm{ab}$ & $3.91 \pm 0.29 \mathrm{~b}$ \\
\hline $\mathrm{CS}(\mathrm{WE})_{\text {Lys }}$ & $31.3 \pm 1.67 \mathrm{ab}$ & $31.6 \pm 0.99 \mathrm{a}$ & $31.1 \pm 1.58 \mathrm{~b}$ & $30.3 \pm 2.22 \mathrm{~b}$ & $29.3 \pm 1.75 \mathrm{c}$ \\
\hline $\mathrm{CS}(\mathrm{MH})_{\mathrm{Lys}}$ & $39.8 \pm 2.13 \mathrm{ab}$ & $40.2 \pm 1.53 \mathrm{a}$ & $39.6 \pm 2.02 \mathrm{~b}$ & $38.5 \pm 2.82 \mathrm{c}$ & $37.27 \pm 2.23 \mathrm{c}$ \\
\hline $\begin{array}{l}\Sigma \text { Exogenous amino } \\
\text { acids (EAA) }\end{array}$ & $25.02 \pm 1.34 \mathrm{a}$ & $26.24 \pm 1.03 \mathrm{a}$ & $25.05 \pm 1.28 \mathrm{a}$ & $25.63 \pm 1.88 \mathrm{a}$ & $23.97 \pm 1.44 \mathrm{a}$ \\
\hline
\end{tabular}

CS-chemical score of restrictive amino acid; WE - whole egg protein standards; MH-mature human, Different letters in the same line indicate significant differences ( $p<0.05$, Duncan's multiple range test).

The highest amount of amino acids (EAA) was assessed (26.24 g $100 \mathrm{~g}^{-1}$ of protein) in wheat grain from the treatment where exclusively mineral fertilizers was used (Table 4). The treatments with municipal sewage sludge from mechanical-biological treatment plant (SS1), with pig manure (PM) and the unfertilized object (0) were

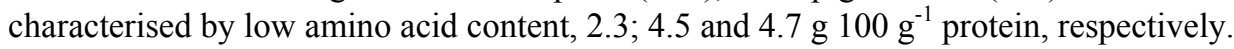

A comparison of the analyzed amino acids with standards (WE and MH) shows their lower content (FAO/WHO, 1991; Hidvegi and Bekes, 1984). Among the amino acids present in animal feeds, lysine, methionine and threonine are considerably deficient protein components. On the basis of the experiment and on amino acid composition of the mature human protein and whole egg protein it was established that in conditions of the experiment, the amino acid limiting protein quality was lysine (Table 4).

\section{Discussion}

Numerous results of research on sewage sludge demonstrate its advantageous effect on biomass production (Mohammad \& Athamneh, 2004; Jamil et al., 2006). Considerable dynamic of the processes occurring in soil, which depends on sometimes quire frequently changing environmental factors strongly modifies the effect of fertilization on growth and development (Pellerin et al., 2000) and chemical composition of plants (Mallarino et al., 1999). The investigations demonstrated a lesser influence on wheat grain yield (in the first year of the experiment 2005) of fertilization with not only sewage sludge but also with pig manure, i.e. on the treatments where nitrogen was supplied in the first year exclusively with these materials. Significantly lower wheat grain yield gathered from these treatments in the first year of the experiment resulted in a difficult plant access to nutrients, mainly nitrogen, whose availability from sewage sludge is the function of climatic conditions during the vegetation period, the dose of applied sewage sludge and the value of C:N ratio (Barbartik et al., 1985; Pescod, 1992). In the presented research such apparent regression in wheat grain yield noted in the first year of the experiment might have been additionally determined by the spring term when sewage sludge was applied. Spring application of natural fertilizers (pig manure) or organic waste materials (sewage sludge) results in limited nutrient availability to plants but on the other hand significantly limits fertilizer component losses, which released from their organic complexes and not absorbed by plants become dispersed in the environment.

Analysis of wheat grain over a longer period of time (3 years) revealed that with time a residual effect of sewage sludge becomes apparent, which results in an increased wheat grain yield. In case of sewage sludge from mechanical-biological treatment plant (SS1) grain yields larger than those produced on the treatment where 
exclusively mineral fertilizers were used, were obtained in the third year. A beneficial effect of sewage sludge fertilization on Durum wheat biomass yield was also demonstrated by Tamrabet et al. (2009) and Jamil et al. (2004).

The problem of microelement deficiency in human diet and animal feeds occurs in many countries. One of the main reasons for this situation is a considerable consumption of cereal products with low contents of these elements (Ozkan et al., 2007). Microelement concentrations in plant biomass depends on the contents of their available forms in soil. The content and bioavailability of microelements in soil are modified by many factors, among others by soil $\mathrm{pH}$, organic matter content, soil sorption capacity but also plant ability to their uptake and fertilization (Gondek \& Kopeć, 2008). Obtaining high yields for a number of years is connected with a necessary control of plant supply with microelements, therefore confirming the purposefulness of conducted experiments. Cooper content was low in the analyzed grain. According to the data in the paper by Anke (1987) the content was deficient, which markedly decreased grain feed value and may also indirectly determine the quantity and quality of plant yield, because copper is a component of enzymes and proteins which participate in specific metabolic processes. The presented experiment demonstrated a significant relationship between grain copper concentrations and the contents of thyrosine, phenylalanine, lysine, methionine and arginine in wheat grain (Table 5). The soil pH and content of organic matter, to which copper shows great affinity, might limit this element bioavailability. Gondek and Kopeć (2004) stated in their research that forming durable humus with copper complexes may cause the lower efficiency of soil fertilization. Pig manure used for the experiment contained bigger amounts of copper than sewage sludge, still this element concentrations in spring wheat grain biomass were not increasing considerably. Obtained results do not allow stating a significant effect of applied sewage sludge on zinc, manganese and iron concentrations in spring wheat grain in comparison with plants from the treatment fertilized with pig manure. It might resulted from relatively low concentrations of these elements in sewage sludge, however a significant relationship was revealed between these elements contents in wheat grain and the content of some exogenous amino acids in protein (Table 5). Zinc concentrations fell within the range of values optimal for animal nutrition. Iron content was in the lower range of this element optimal level in animal feeds (Anke 1987). The problem of iron deficiency in humans and animals is frequent and generally caused by a low content of bioavailable forms of this element in diet or disturbances in its absorption (Ozkan et al., 2007). Iron uptake by plants may be difficult mainly due to soil reaction. Relatively low content of this element in grain may have also a physiological background connected with its difficult transport from the root system to the aboveground organs and not its limited absorption from soil. Irrespective of the applied fertilization, manganese content in the analyzed wheat grain proved deficient (Anke, 1987). Moreover, disadvantageous manganese level in wheat grain biomass resulted by a bad $\mathrm{Fe}: \mathrm{Mn}$ ratio.

Table 5. Spearman correlation coefficients between zinc, copper, manganese content and grain yield, total protein and exogenous amino acids content

\begin{tabular}{|c|c|c|c|c|}
\hline & $\mathrm{Zn}$ & $\mathrm{Cu}$ & $\mathrm{Mn}$ & $\mathrm{Fe}$ \\
\hline Grain yield & ns & ns & ns & ns \\
\hline Total protein & $0.575 * * *$ & ns & $-0.544 * * *$ & ns \\
\hline Thr & ns & $-0.479 * * *$ & $0.736 * * *$ & $-0.502 *$ \\
\hline Val & ns & ns & $0.623 * * *$ & ns \\
\hline Ile & ns & ns & $0.501 * * *$ & ns \\
\hline Leu & ns & ns & $0.627 * * *$ & ns \\
\hline Phe & ns & $-0.460 * * *$ & $0.675 * * *$ & ns \\
\hline Lys & ns & $0.381 * *$ & $0.717 * * *$ & $-0.485^{*}$ \\
\hline Met & $-0.729 * * *$ & $0.661 * * *$ & $-0.283^{*}$ & ns \\
\hline His & $0.381 * *$ & ns & ns & ns \\
\hline Arg & ns & $-0.430 * * *$ & $0.690 * * *$ & ns \\
\hline $\begin{array}{l}\Sigma \text { Exogenous amino } \\
\text { acids }\end{array}$ & ns & ns & $0.645 * * *$ & ns \\
\hline
\end{tabular}

*** $P<0.001, * * P<0.01, * P<0.05, \mathrm{~ns}=$ not significant; $\mathrm{n}=60$ 
Comparison of the effect of natural and organic fertilizers with mineral fertilizers effect shows a greater influence of mineral fertilization on chemical composition of plants. While using organic waste materials, among others municipal sewage sludge for fertilization, one can expect their beneficial effect not only on the plant yield but also on its biological value. Analyzing the basic chemical composition, which is the determinant of feed nutritional value, we may state that cereal grain is a carbohydrate fodder with low or medium content of total protein (Brand et al., 2003). According to Dubetz and Gardiner (1980) the content of protein and amino acids in wheat grain changes apparently under the influence of increasing nitrogen doses. In the authors' own research the level of nitrogen fertilization was not diversified, whereas application of moderate dose of this element to the soil in the form of mineral fertilizers and organic materials (manure, sewage sludge) contributed to stabilizing the content of analyzed amino acids in spring wheat grain protein. Cereal grain reveals a low content of lysine. In this investigation lysine was the amino acid limiting protein quality in grain from all treatments, both with reference to whole egg protein standard (WE) and to mature human protein standard (MH). Sherry (2007) obtained similar results in his research. Such situation may be a result of the applied fertilization and the nitrogen rate. Proper balancing of amino acids in food doses with animal requirements is of significant importance not only because of utilization of the most valuable component, i.e. feed protein but also because of decreasing the amount of nitrogen released with urine in case of each amino acid excess in relation to needs.

\section{Conclusion}

Difficult plant access to nitrogen as a whole supplied with sewage sludge may to a considerable degree determine the quantity and quality of yields, particularly in the year when fertilization was applied. A better result of fertilizer effect of sewage sludge may be obtained due to cooperation of these materials with mineral fertilizers.

Application of sewage sludge in moderate doses compatible with plant requirements for nutrients does not cause worsening of the yield biological value.

Independently of the applied fertilization, the microelements limiting fodder value of spring wheat grain were copper and manganese, whereas protein quality was determined by lysine concentration.

\section{References}

Ahmad, B., Bakhsh, K., \& Hassan, S. (2006). Effect of sewage water on spinach yield. International Journal of Agriculture and Biology, 8, 423-425.

Anke, M. (1987). Toxizitatsgrenzwerte fur spurenenelemente in futtermitteln. Schwermetalle in der umwelt. Kolloquien des Instituts fur Pflanzenernahrung, 2, 110-127.

AOAC. (1990). Official methods of analysis. $15^{\text {th }}$ Edition Association of Official Analytical Chemists. Arlington, VA.

Baran, S., \& Turski, R. (1996). Specialist exercises on waste and sewage disposal (p. 136). Wyd. AR w Lublinie.

Barbartik, A., Lawarbance, J. R., Sikpra, J., \& Colacicco, D. (1985). Factors affecting the mineralization of nitrogen in sewage sludge applied to soil. American Journal of Soil Science, 49, 1403-1406. http://dx.doi.org/10.2136/sssaj1985.03615995004900060014x

Bęza, R. (1967). Amino acids in animal nutrition. Wyd. PWRiL, Warszawa.

Block, R. J., \& Mitchell, H. H. (1946). The correlation of the amino acid composition of proteins with their nutritive value. Nutrition Abstracts \& Reviews, 16, 249.

Bouzerzour, H., Tamrabet, L., \& Kribaa, M. (2002). Response of barley and oat to the wastewater irrigation and to the sludge amendment. In The Proc. Int. Seminar: Biol. and Environ. (pp. 71), University Mentouri, Constantine, Algeria

Brand, T. S., Cruyweggen, C. W., Brandt, D. A., Viljoen, M., \& Burger, W. W. (2003). Variation in the chemical composition, physical characteristics and energy values of cereal grains produced in the Western Cape area of South Africa. South African Journal of Animal Science, 33, 117-126. http://dx.doi.org/10.4314/sajas.v33i2.3765

Burzyński, M., \& Buczek, J. (1989). Interaction between cadmium and molybdenum affecting the chlorophyll content and accumulation of some heavy metals in the second leaf of Cucumis sativus L. Acta Physiologiae Plantarum, 11, 137-146.

Chaudri, A. M., Allan, C. M. G., Badawy, S. H., Adams, M. L., McGrath, S. P., \& Chambers, B. J. (2001). Cadmium content of wheat grain from a long-term field experiment with sewage sludge. Journal of Environmental Quality, 30, 1575-1580. http://dx.doi.org/10.2134/jeq2001.3051575x 
Dubetz, S., \& Gardiner, E. E. (1980). Protein content and amino acid composition of seven wheat cultivars subjected to water stress: Effects of nitrogen fertilizer treatments. Journal of Plant Nutrition, 2(5), 517-523. http://dx.doi.org/10.1080/01904168009362794

FAO/WHO. (1991). Protein quality evaluation. Report of Joint FAO-WHO Expert Consultation. FAO Food and Nutrition, 51, 4-8.

Gondek, K. (2006a). Content of various forms of cadmium, copper, lead and chromium in soil after application of untreated and composted tannery sewage sludge. Plant, Soil and Environment, 52(5), 199-210.

Gondek, K. \& Kopeć, M., (2004). Heavy metal binding by humus in soil of long-term static fertilizer experiment at Czarny Potok. Ecological Chemical Engineering, 11(7), 561-572.

Gondek, K., \& Kopeć, M. (2008). Studies on the contents and amounts of microelements taken up by meadow sward in conditions of long-term and diversified mineral fertilization as to the sward fodder value. Polish Journal of Social Science, 23(1), 1-15.

Hidvégi, M., \& Békés, F. (1984). Mathematical modeling of protein quality from amino acid composition. (In:) Proceeding of International Association of Cereal Chemistry. Symposium, Akademiai Kiadó, Budapeszt, 205-286.

IUSS Working Group WRB. World Reference Base for Soil Resources. (2006). first update 2007. World Soil Resources Reports, No. 103. FAO, Rome.

Jamil, M., Qasim, M., Umar, M., \& Rehman, K. (2004). Impact of organic wastes (sewage sludge) on the yield of wheat (Triticum aestivum L.) in a calcareous soil. International Journal of Agriculture and Biology, 6, 465-467.

Jamil, M., Qacim, M., \& Umar, M. (2006). Utilization of sewage sludge as organic fertilizer in sustainable agriculture. Journal of Applied Sciences, 6, 531-535. http://dx.doi.org/10.3923/jas.2006.531.535

Keller, C., McGarth, S. P., \& Durham, S. J. (2002). Trace metals leaching through a soil-grassland system after sewage sludge application Journal of Environmental Quality, 31, 1550-1560. http://dx.doi.org/10.2134/jeq2002.1550

Korboulewsky, N., Dupouyet, S., \& Bonin, G. (2002). Environmental risk of applying sewage sludge compost to vineyards. Journal of Environmental Quality, 31, 1522-1527. http://dx.doi.org/10.2134/jeq2002.1522

Krzywy, E. (1999). Environmental management of sewage and sludge (p. 145). Wyd. AR w Szczecinie.

Lavado, R. S., Rodriguez, M. B., \& Taboada, M. A. (2005). Treatment with biosolids affects soil availability and plant uptake of potentially toxic elements. Agriculture, Ecosystems \& Environment, 109(3-4), 360-364. http://dx.doi.org/10.1016/j.agee.2005.03.010

Mallarino, A. P., Bordoli, J. M., \& Borges, R. (1999). Phosphorus and potassium placement effects on early growth and nutrient uptake of no-till corn and relationships grain yield. Agronomy Journal, 91(1), 37-45. http://dx.doi.org/10.2134/agronj1999.00021962009100010007x

Mohammad, M. J., \& Athamneh, B. M. (2004). Changes in soil fertility and plant uptake of nutrients and heavy metals in response to sewage sludge application to calcareous soils. Agronomy Journal, 3, 229-236. http://dx.doi.org/10.3923/ja.2004.229.236

Ostrowska, A., Gawliński, A., \& Szczubiałka, Z. (1991). Methods of analysis and assessment of soil and plant properties. Edited by Institute of Environmental Protection, 1-324. (In Polish)

Ozkan, H., Brandolini, A., Torun, A., Altlntas, S., Eker, S., Kilian, B., .. Cakmak, I. (2007). Natural variation and identification of microelements content in seeds of einkorn wheat (Triticum monococcum). Developments in Plant Breeding, 12, 455-462. http://dx.doi.org/10.1007/1-4020-5497-1_55

Pellerin, S., Mollier, A., \& Plénet, D. (2000). Phosphorus deficiency affects the rate of emergence and number of maize adventitious nodal roots. Agronomy Journal, 92, 690-697.

Pescod, M. B. (1992). Wastewater Treatment and Use in Agriculture (p. 117). FAO irrigation and drainage Publication, 47, Rome, Italy.

Prasad, M. N. W. (1995). Inhibition of maize leaf chlorophylls, carotenoids and gas exchange functions by cadmium. Photosynthetica, 31, 635-640.

Rüegsegger, A., Schmutz, D., \& Brunold, C. (1990). Regulation of glutathione synthesis by cadmium in Pisum sativum L. Plant Physiology, 93, 1579-1584. http://dx.doi.org/10.1104/pp.93.4.1579 
Sastre, I., Vicente, M. A., \& Lobo, M. C. (2001). Behaviour of cadmium and nickel in a soil amended with sewage sludge. Land Degradation \& Development, 12(1), 27-33. http://dx.doi.org/10.1002/ldr.421

Sherry, P. R. (2007). Improving the protein content and composition of cereal grain. Journal of Cereal Science, 46, 239-250. http://dx.doi.org/10.1016/j.jcs.2007.06.006

Tamrabet, L., Bouzerzour, H., Kribaa, M., \& Makhlouf, M. (2009). The effect of sewage sludge application on durum wheat (Triticum durum). Journal of Agriculture and Biology, 11, 741-745. 